\title{
Combustion at the late Early Pleistocene site of Cueva Negra del Estrecho del Río Quípar (Murcia, Spain)
}

M.J. Walker ${ }^{1,2}$, D. Anesin ${ }^{3}$, D.E. Angelucci ${ }^{3}$, A. Avilés-Fernández ${ }^{1,2}$, F. Berna ${ }^{4}$, A.T. Buitrago-López ${ }^{1,2}$, Y. Fernández-Jalvo ${ }^{5}$, M. Haber-Uriarte ${ }^{1,2}$, A. López-Jiménez ${ }^{1,2}$, M. López-Martínez ${ }^{1,2}$, I. Martín-Lerma ${ }^{1,2}$, J. Ortega-Rodrigáñez ${ }^{1,2}$, J.-L. Polo-Camacho ${ }^{1,2}$, S.E. Rhodes ${ }^{6}$, D. Richter ${ }^{7,8,9}$, T. Rodríguez-Estrella ${ }^{1,2,10}$, J.-L. Schwenninger ${ }^{11} \&$ A.R. Skinner ${ }^{12}$

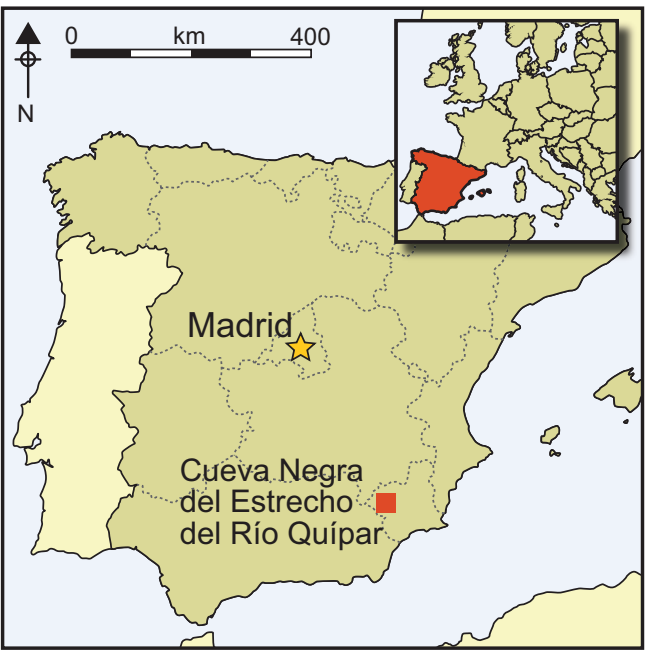

Control of fire was a hallmark of developing human cognition and an essential technology for the colonisation of cooler latitudes. In Europe, the earliest evidence comes from recent work at the site of Cueva Negra del Estrecho del Rio Quipar in south-eastern Spain. Charred and calcined bone and thermally altered chert were recovered from a deep, 0.8-million-year-old sedimentary deposit. A combination of analyses indicated that these had been heated to $400-600^{\circ} \mathrm{C}$, compatible with burning. Inspection of the sediment and hydroxyapatite also suggests combustion and degradation of the bone. The results provide new insight into Early Palaeolithic use of fire and its significance for buman evolution.

Keywords: Early Pleistocene, Palaeolithic, Acheulean, combustion, cognitive evolution

1 Murcia University Experimental Sciences Research Group E005-11 'Quaternary Palaeoecology, Palaeoanthropology and Technology', Biology Faculty, Murcia University, Campus Universitario de Espinardo Edificio 20, 30100 Murcia, Spain (Email:mjwalke@gmail.com)

2 Murcian Association for the Study of Palaeoanthropology and the Quaternary (MUPANTQUAT), Museo Arqueologico de Murcia, PO Box 4123, 30080 Murcia, Spain

3 'B. Bagolini' Laboratory for Prehistoric and Medieval Archaeology and Historical Geography, Department of Humanities, Trento University, via T. Gar 14, I-38122 Trento, Italy

4 Department of Archaeology, Simon Fraser University, 888 University Drive, Burnaby, BC V5A 1S6, Canada

5 Department of Palaeobiology, National Museum of Natural Sciences of the Spanish National Research Council, Calle José Gutiérrez Abascal 2, 28006 Madrid, Spain 


\section{Introduction}

When do traces of combustion first appear at middle-latitude Palaeolithic sites? What do they say about cognitive evolution in early Homo dispersing throughout Eurasia? Inferences that European sites lacked fire before 0.5-0.4 Ma (Roebroeks \& Villa 2011) rely on the absence of hearths enabling heat-control. Combustion, however, existed $c$. $0.8 \mathrm{Ma}$, without hearths, in the south-eastern Spanish rockshelter of Cueva Negra del Estrecho del Río Quípar (CNERQ). Cognitive versatility perhaps enabled opportunistic exploitation of bush-fires outside such that fire could be tended inside, albeit without heatcontrol.

Thermally affected fragments of bone, chert artefacts, nodules, fragments and spalls come from closed, deeply lying sediment in unit VI at CNERQ (lat. 38.03679; long. $-1.88494 ; 740 \mathrm{~m}$ asl; $10 \mathrm{~km}$ south of Caravaca). Systematic excavation since 1990 of $5 \mathrm{~m}$-deep Pleistocene sediments lying on bed-rock uncovered abundant small Palaeolithic artefacts, on chert and other rock types (Walker et al. 2013, 2016), showing consistency throughout the stratigraphic sequence, including flakes removed by repetitive centripetal striking of small discoidal cores, fragments and flakes with steeply retouched edges, keeled forms and trihedral pieces with spurred points (cf. Debénath \& Dibble 1994: 99, figs 7.227.27, 108-109, figs 8.29-8.37), and a bifacially flaked ('Acheulean') limestone handaxe (Walker et al. 2013). Chert is absent in the Upper Miocene (Tortonian) biocalcarenite cave walls; most chert came from an older Tortonian conglomerate outcrop $0.8 \mathrm{~km}$ east of CNERQ, although comparative trace-element analyses by laser-ablation inductively coupled plasma mass-spectrometry suggests some excavated chert originated around $30 \mathrm{~km}$ away (Zack et al. 2013).

Magnetostratigraphy assigns the entire cave sediment to the Matuyama chron, $>0.78 \mathrm{Ma}$ (Scott \& Gibert 2009). Preliminary thermoluminescence dating of heated flint by author D.R. (unpublished) agrees with single-grain optically stimulated luminescence analysis by author J.-L.S (unpublished), indicating $>0.5 \mathrm{Ma}$, although small sample size and signal saturation preclude accuracy; hitherto, less accurate multiple-grain OSL methodology suggested 0.3-0.5 Ma (Walker et al. 2006). Regrettably, ${ }^{26} \mathrm{Al} /{ }^{10} \mathrm{Be}$ analysis implausibly indicated Plio-Pleistocene antiquity (R. Braucher pers. comm.).

Biostratigraphy of micro- and macro-mammalian remains assigns the deposits to $<1.0$ >0.7 Ma (Walker et al. 2013, 2016). Extinct Arvicolid rodents (Table 1) of the Iberian

6 Institut für Naturwissenschaftliche Archäologie-Archäozoologie, Universität Tübingen, Rümelinstrasse 23, D72070 Tübingen, Germany

7 Department of Human Evolution, Max Planck Institute for Evolutionary Anthropology, Deutscher Platz 6, D-04103 Leipzig, Germany

8 Lehrstuhl Geomorphologie, Universität Bayreuth, Universitätsstrasse 30, D-95447 Bayreuth, Germany

$9 \quad$ Institut für Okologie, Leuphana Universität Lüneburg, Scharnhorststrasse 1, 21335 Lüneburg, Germany

10 Department of Mining Engineering, Geology and Cartography, Cartagena Polytechnic University, Plaza Cronista Isidoro Valverde, Edificio 'La Milagrosa', 30202 Cartagena, Spain

11 Research Laboratory for Archaeology and the History of Art, Oxford University, Dyson Perrins Building, South Parks Road, Oxford OX1 3QY, UK

12 Department of Chemistry, Williams College, 880 Main Street, Williamstown, MA 01267, USA

(C) Antiquity Publications Ltd, 2016 
Table 1. Some extinct small mammal species excavated at Cueva Negra. Numbers are of finds identified for each species.

\begin{tabular}{lccccc}
\hline & \multicolumn{5}{c}{ Excavated units } \\
\cline { 2 - 6 } Taxa & Unit II & Unit III & Unit IV & Unit V & Unit VI \\
\hline & & & & & \\
Pliomys episcopalis & 1 & 9 & - & - & 1 \\
Mimomys savini & 7 & 17 & 4 & 1 & 5 \\
Microtus (Iberomys) huescarensis & 21 & 101 & 42 & 1 & 26 \\
Microtus (Stenocranius) gregaloides & - & 3 & - & - & - \\
Microtus (Terricola) arvalidens & - & 2 & - & - & - \\
Microtus (Allophaiomys/Victoriamys) chalinei & 40 & 45 & 49 & 8 & 13 \\
Allocricetus bursae & 9 & 3 & 2 & - & - \\
Apodemus cf. sylvaticus & 13 & 13 & 16 & 1 & 3 \\
Eliomys quercinus & 1 & 1 & 2 & - & - \\
Crocidura sp. & 8 & 39 & 27 & 1 & 13 \\
Neomys sp. & 2 & 11 & 4 & - & - \\
Erinaceus europaeus & 43 & 29 & 6 & - & - \\
Oryctolagus cf. giberti & 87 & 84 & 24 & 4 & 30 \\
Prolagus calpensis & 12 & 21 & 20 & - & 11 \\
\hline
\end{tabular}

For Arvicolid rodents (Pliomys; Mimomys; Microtus) numbers refer to mandibular first molars; for other Rodentia (Allocricetus; Apodemus; Eliomys) and for Eulipotyphla (Crocidura; Neomys; Erinaceus), they refer to maxillary and mandibular molars; for Lagomorpha, in Oryctolagus they refer to mandibular third premolars; and in Prolagus they refer to different molars.

late Early Pleistocene occur from top to bottom of the sedimentary sequence (note that upper units II, III and IV have been excavated over a wider area than deeper units V and VI). Once surmised as faunal atavisms c. $0.5 \mathrm{Ma}$ (Walker et al. 2006), the now extensive Arvicolid sample is comparable to Iberian late Early Pleistocene samples from Atapuerca and the Guadix-Orce Basin (Walker et al. 2016). Macro-mammalian revision by J. van der Made (Walker et al. 2016) shows the presence, even in upper units, of late Early Pleistocene taxa (e.g. Dama vallonnetensis), correcting misguided designations (e.g. Stephanorhinus hemitoechus in Walker et al. (2004), which is either S. etruscus or $S$. hundsheimensis) unduly influenced by older publications (Martínez Andreu et al. 1989).

The sediments are near-horizontally bedded, laminated or cross-bedded bands or lenses of fine (silt-/sand-sized) particles of litharenite, micritic limestone and quartz, with sparse coarser components. Macroscopic inspection and micromorphology demonstrate several cycles of alluviation (Angelucci et al. 2013) when the cave lay beside a swampy lake that overflowed into it intermittently. Middle/Upper Pleistocene neotectonic activity and riverine incision produced today's vertical $40 \mathrm{~m}$ separation. Throughout the sequence, there is ample evidence of Palaeolithic activity, doubtless during dry seasons. Apart from a drier episode, reflected in the upper part of the sequence by an incipient palaeosol with traces of bioturbation subsequently truncated by erosion (Angelucci et al. 2013), no significant discontinuity exists (pace Jiménez-Arenas et al. 2011), and the sediments 

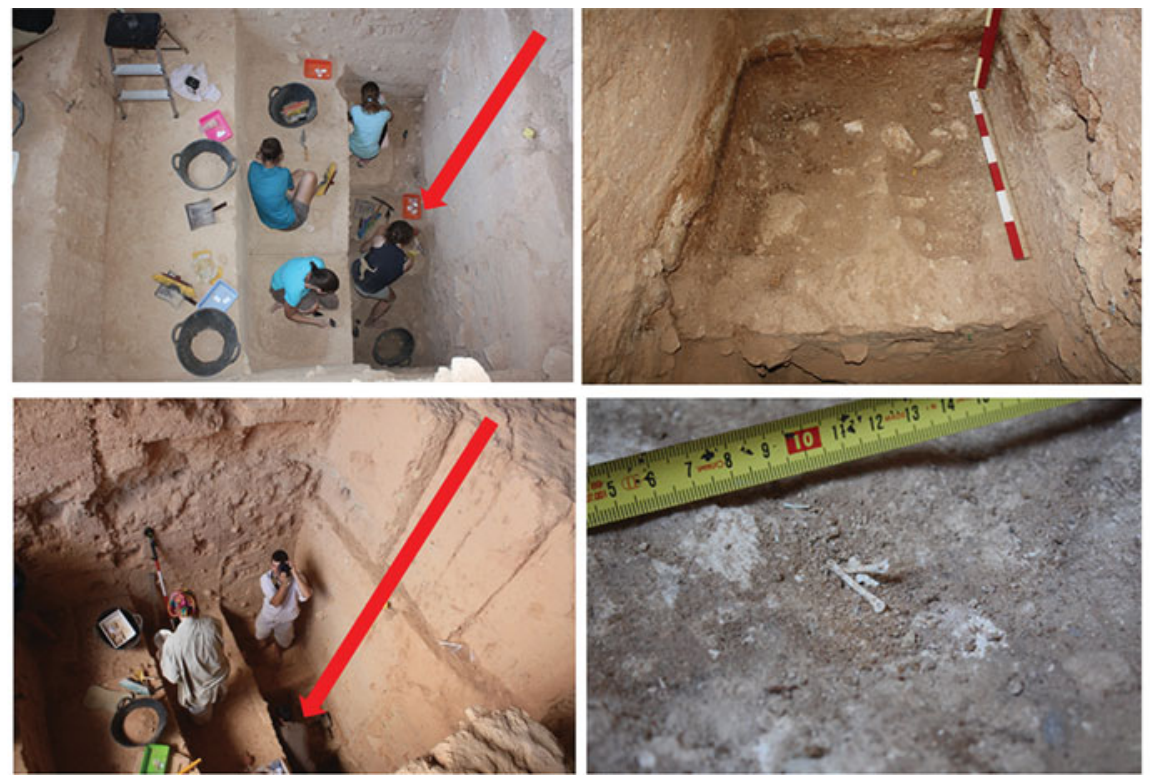

Figure 1. The Cueva Negra del Estrecho del Rio Quipar excavation. The deep-lying deposit containing burnt remains is indicated by red arrows and is shown in the close-up views on the right.

remained undisturbed (save for small pits dug c. 1940). Pollen from the sediments attests to mild, humid conditions with gallery woodland (Carrión et al. 2003), and diving-duck bones require a nearby lake (Walker et al. 2004). The sediments probably formed in the late Early Pleistocene MIS21 (NB publications before Scott and Gibert (2009) regarded them as Middle Pleistocene).

\section{Excavation and macroscopic consideration of thermally affected bone and chert}

Findings that fire had affected both bone fragments and Palaeolithic chert came to light in 2011 during excavation in $1 \mathrm{~m}^{2}$ of sediment around $0.1 \mathrm{~m}$ thick at the top of unit VI (Walker et al. 2013), $4.5 \mathrm{~m}$ beneath the surface of the sedimentary sequence, $6-7 \mathrm{~m}$ behind the cave mouth (Figure 1). Hitherto, thermally altered lithics were unknown among $>3000$ pieces excavated, and barely a score of burnt bone fragments were scattered among $>40000$ faunal items recovered. The 2011 excavation uncovered $>165$ thermally altered chert items, around $0.5-5 \mathrm{~mm}$ in size, shattered by combustion (and 10 of limestone, 5 of quartzite and, in 2012, a radiolarite edge-retouched 'scraper'). Among numerous charred bone fragments are several white calcined ones (Figure 2) including conjoinable fragments caused by lengthwise long-bone spalling typical of circumferential shrinkage after thermal volatilisation of organic components at $800-900^{\circ} \mathrm{C}$ (cf. Uberlaker 1999 [2004]: 35-38). Since 2012, more burnt fragments of chert and bone have been excavated from a further 


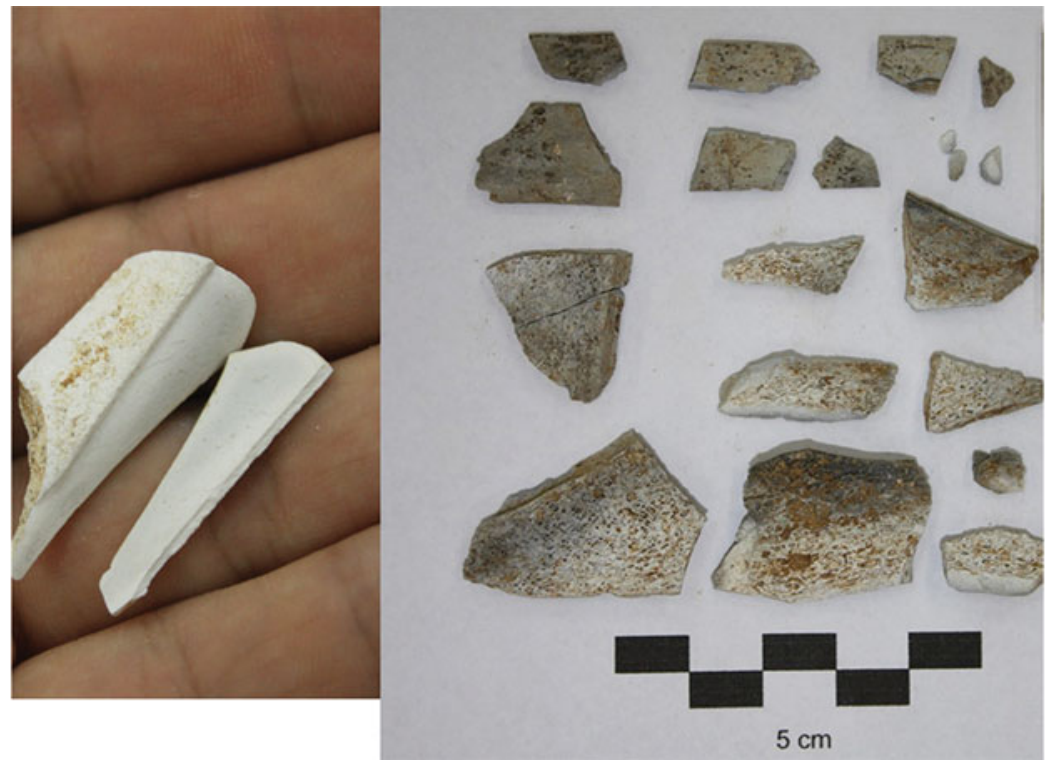

Figure 2. Thermally altered bone fragments. The left-hand photograph shows longitudinal spalling.

$1.5 \mathrm{~m}^{2}$ of the $5 \mathrm{~m}^{2}$ area where thermally altered sediment is now exposed as a combustion area, apparently continuing inwards and outwards below $4.5 \mathrm{~m}$ of overburden, perhaps a bonfire site, although neither a circumscribed 'feature' nor 'hearth'. Methodological requirements to wash excavated overlying sediment on $2 \mathrm{~mm}$ mesh sieves constrain excavation.

One excavated thermally altered chert nodule (Figure 3, top), split open by heat ('thermal shock'), had several minute, razor-sharp splinters still in place (implying negligible displacement), its split surface bearing shallow rippled depressions typical of thermally altered chert fracturing (cf. Richter 2007; cf. Schön 2012: 104, fig. 4). An artificially struck flake (Figure 3, bottom) was excavated with sharp conjoinable fragments in apposition. Effects of combustion on chert are well documented although far from uniform, owing to the variety and complexity of cherts. In some cherts, temperatures around $250-300^{\circ} \mathrm{C}$ produce changes in colour, lustre or even heat-damage or recrystallisation of quartz. In others, temperatures around $500^{\circ} \mathrm{C}$ are needed for heat-damage or recrystallisation, depending on the chemical and crystalline properties of the quartz or impurities in the chert, e.g. calcium carbonate or water (Luedtke 1992; Clemente Conte 1997). Combustion temperatures cannot be inferred accurately from visual inspection of burnt chert; supplementary analytical procedures and specific studies are necessary. Chert tends to shatter at around $700-800^{\circ} \mathrm{C}$ into splinters, spalls and chips far too small for the application of laboratory techniques, so larger burnt fragments on which they were applied had probably not undergone prehistoric heating $>700^{\circ} \mathrm{C}$, therefore laboratory palaeotemperature determinations probably underestimate temperatures reached by fire. The deep CNERQ sediment has 

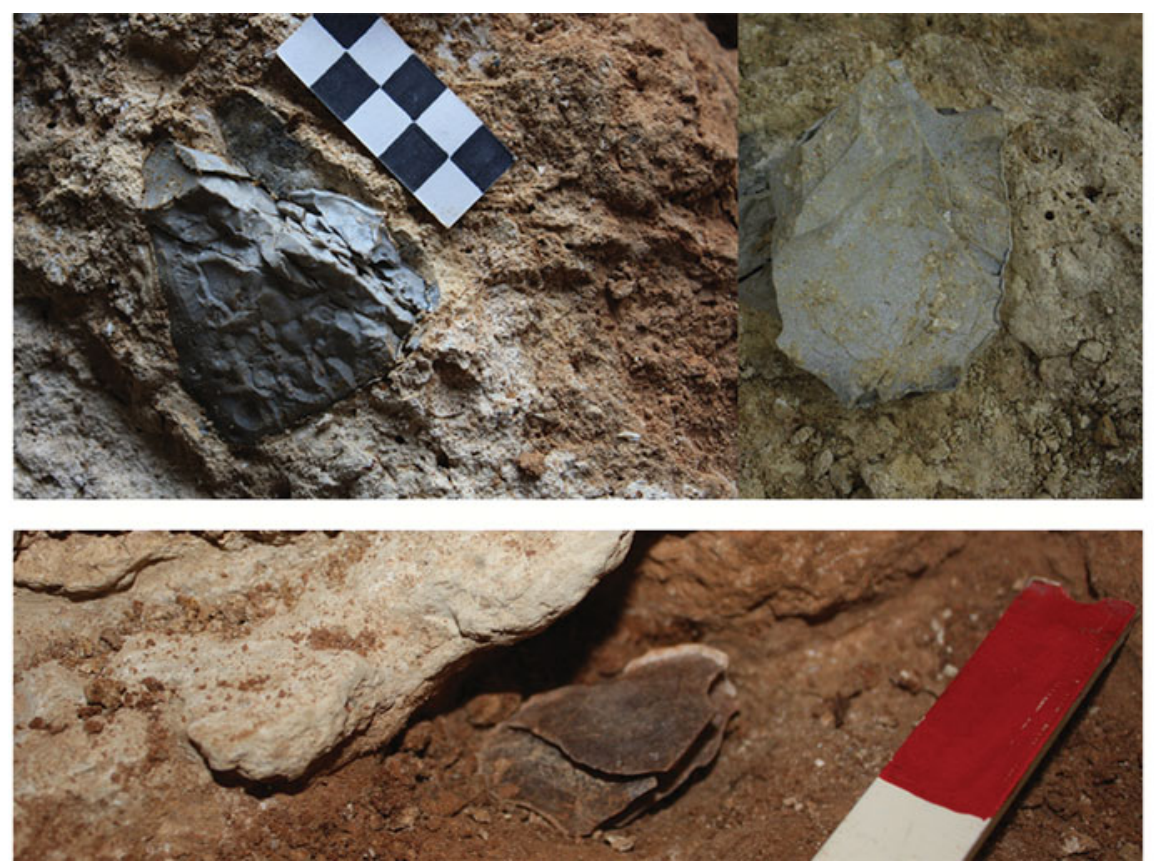

Figure 3. Top left: thermally altered chert nodule. Top right: the rippled surface of a large fragment of the same nodule that covered the fragments on the left, including several small splinters (difference in colour is exaggerated by lighting differences). Bottom: flint flake found in three fragments in situ. Red part of scale $=25 \mathrm{~mm}$.

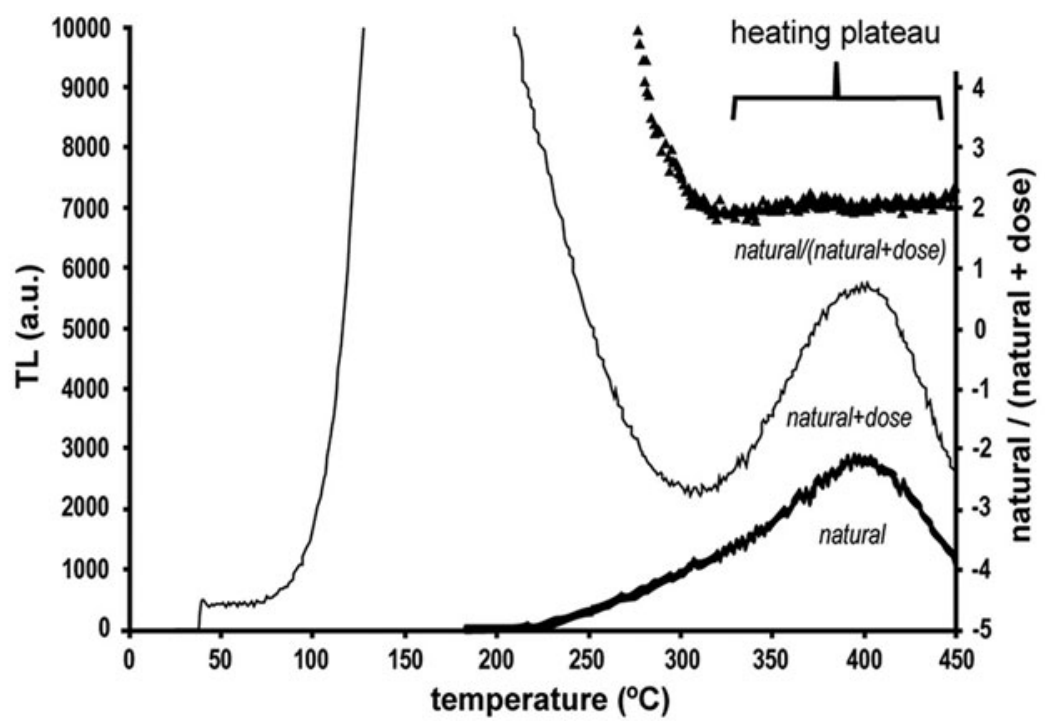

Figure 4. Thermoluminescence (TL) analysis of burnt chert. The constant ratio (heating plateau) of natural/(natural+dose) TL signals indicates heating above $400^{\circ} \mathrm{C}$.

(C) Antiquity Publications Ltd, 2016 


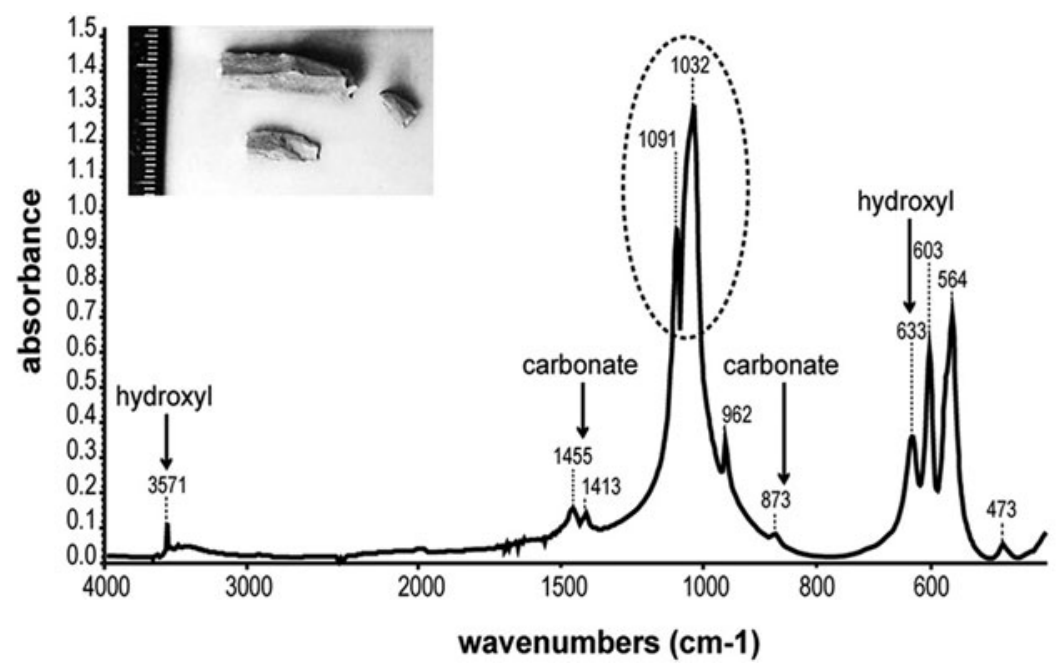

Figure 5. Fourier transform infrared (FTIR) spectroscopic analysis of burnt bone. Note the characteristic sharpening of the phosphate absorptions at 1032-1091 and hydroxyl bands when bone mineral is heated above $400-450^{\circ} \mathrm{C}$, although residual carbonate absorptions indicate an incomplete calcination process, implying a temperature $<700-800^{\circ} \mathrm{C}$. Sample shown inset.

provided many splinters, spalls and chips, often with microscopic stigmata of thermal alteration.

\section{Analytical procedures, specific studies and summary of principal conclusions}

Observations made at excavation were supplemented with analytical procedures and specific studies:

a) Thermoluminescence analysis of an excavated burnt chert fragment showed that high temperature of the main TL peak, strong signal increase and presence of a well-developed heating plateau indicate ancient heating $>400^{\circ} \mathrm{C}$ (Figure 4).

b) Fourier transform infrared (FTIR) spectroscopy of an excavated bone fragment found characteristic sharpening of phosphate absorptions at 1032-1091 and hydroxyl bands that appear on heating bone mineral $>400-450^{\circ} \mathrm{C}$ (Figure 5), while residual carbonate absorptions indicate incomplete calcination, at $<700-800^{\circ} \mathrm{C}$.

c) ESR spectra of three excavated bone fragments were compared. Two had undergone Palaeolithic burning; an apparently unburnt fragment was heated as a control. ESR palaeothermometry (Skinner et al. 2004) involves identifying residual carbon fragments containing 'soot' radicals resulting from radiation damage to bone matrix (causing thermal fragmentation of collagen), with oxidation of manganese around $400-500^{\circ} \mathrm{C}$. Modern bones contain so much carbon that, on heating, the peak due to pure carbon (basically soot) is so wide that it conceals the other peaks. When fossil bones have lost most, but not all, of their organic carbon, ESR palaeothermometry can estimate temperatures to which bones were heated in 
antiquity. One burnt CNERQ fragment afforded an organic radical signal additional to that of manganese, indicating ancient heating at approximately $400-450^{\circ} \mathrm{C}$ (Figure 6 ,
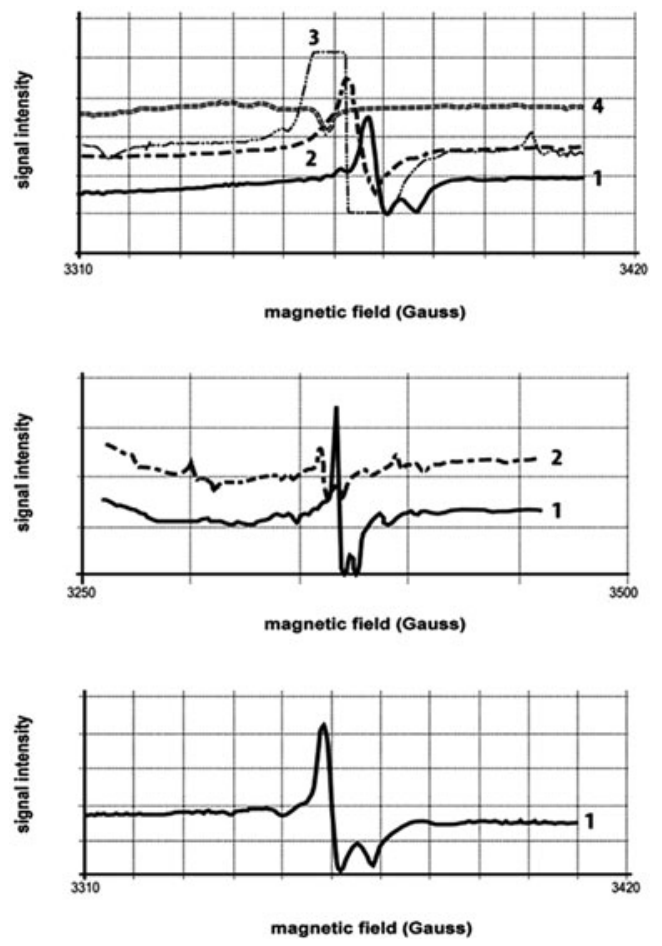

Figure 6. Electron spin resonance (ESR) analyses of bone. Top: fossil bone from Cueva Negra, used as control ( $1=$ unheated, showing 'dating peak'; 2 = heated to $300^{\circ} \mathrm{C}$; $3=$ heated to $450^{\circ} \mathrm{C} ; 4=$ heated to $600^{\circ} \mathrm{C}$ ). Centre: two fragments of a fossil bone from Cueva Negra, apparently heated in antiquity; both showed Mn peaks as well as organic radicals. Best estimate of heating temperature: $400-450^{\circ} \mathrm{C}$. Bottom: fragment offossil bone from Cueva Negra, described as 'calcined'. Best estimate of heating temperature: $<600^{\circ} \mathrm{C}$. Additional information is available in online supplementary material. d) Thermal discolouration of excavated bone is supported by taphonomic analysis, combined with SEM and EDX, enabling sporadic isolated deposits on bone surfaces of oxides of manganese or iron to be distinguished from discolouration attributable to thermal alteration (Figure 7, following Fernández-Jalvo \& Avery 2015). A statistically significant contrast exists between the proportion of micro-mammalian bone fragments $(<5 \mathrm{~kg}$ liveweight) showing colour change, consistent with exposure to heat, as against those showing less change, when samples from upper unit VI containing burnt chert and bone were compared with samples from unit $\mathrm{V}$ above and lower unit VI sediment below. In a taphonomic analysis of around 2300 micro-mammalian bone fragments, identified among around 4400 micro-faunal fragments from those sedimentary units (Rhodes 2014; Rhodes

(C) Antiquity Publications Ltd, 2016 centre). Other CNERQ bones lacked sufficient carbon to show effects of heating, which is unsurprising because bones, being porous, both lose material over time and absorb material from the environment; moreover, organic carbon breaks down during fossilisation, aided by bacteria, and resulting fragments are leached from bone by ground water.

Fossil bone can show a 'dating peak' due to radiation damage to carbonate in the bone matrix. Bone heated in antiquity will show this, superimposed on other spectral features. Bones cannot be dated from this peak because the environmental radiation dose, especially internal to the bone, is incalculable. Radioisotopes, largely uranium, can leach in and out of bone during its burial history. Although this dating signal is extraordinarily stable, it decreases when heated at around $300^{\circ} \mathrm{C}$ for several hours. Thus, the pattern sought on artificial heating of fossil bone is the disappearance of the 'dating signal' and its replacement by a structure attributable to carbon fragments, with a central peak due to carbon (soot) radicals. Peaks at around $400-500^{\circ} \mathrm{C}$ appear due to oxidation of manganese by heat. By $600^{\circ} \mathrm{C}$, almost everything disappears apart from, perhaps, residual carbon radical intensity (Figure 6, top). 
Findings, context and significance of combustion at the late Early Pleistocene
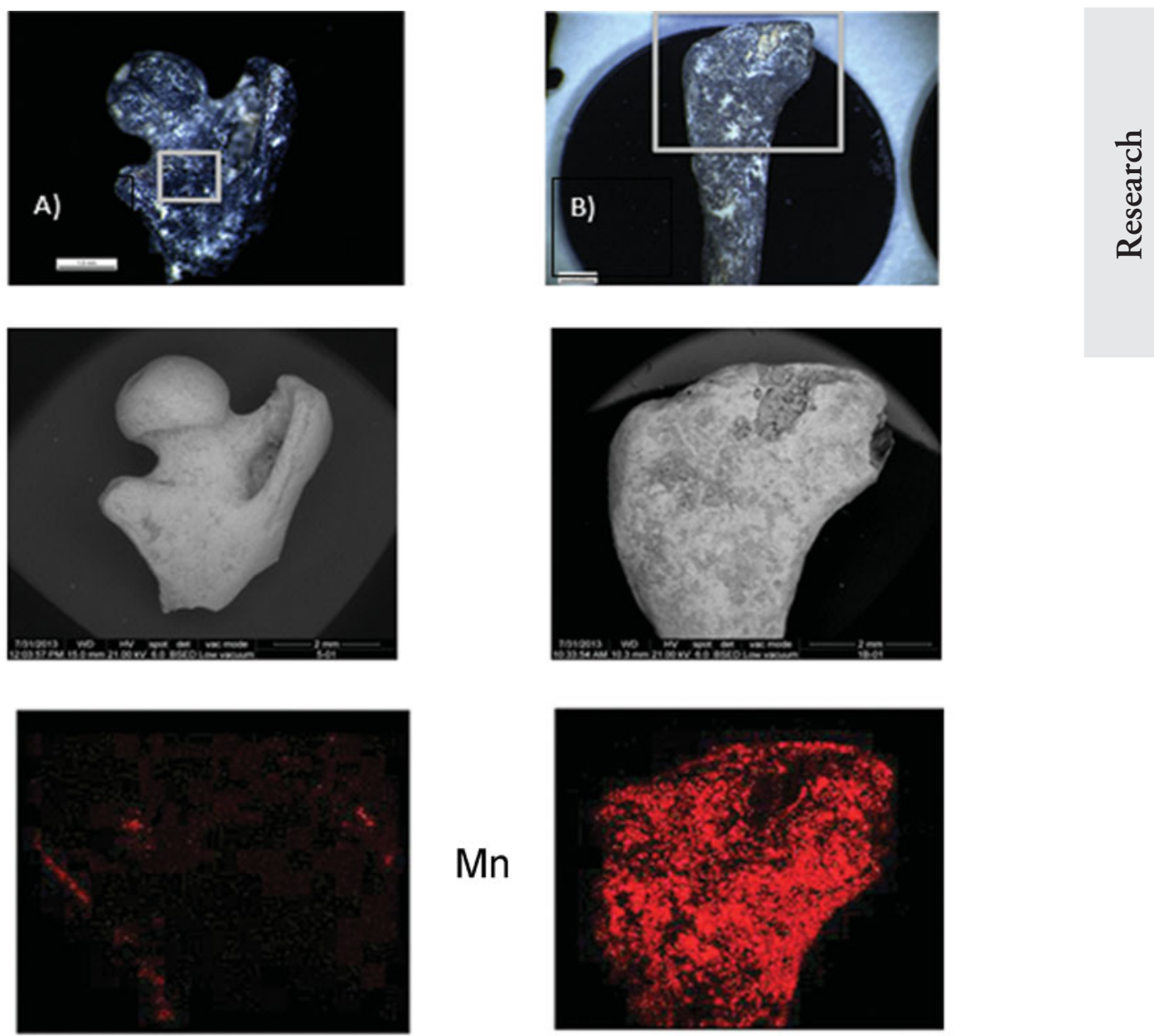

tho Ka1

$\operatorname{tin} K a 1$
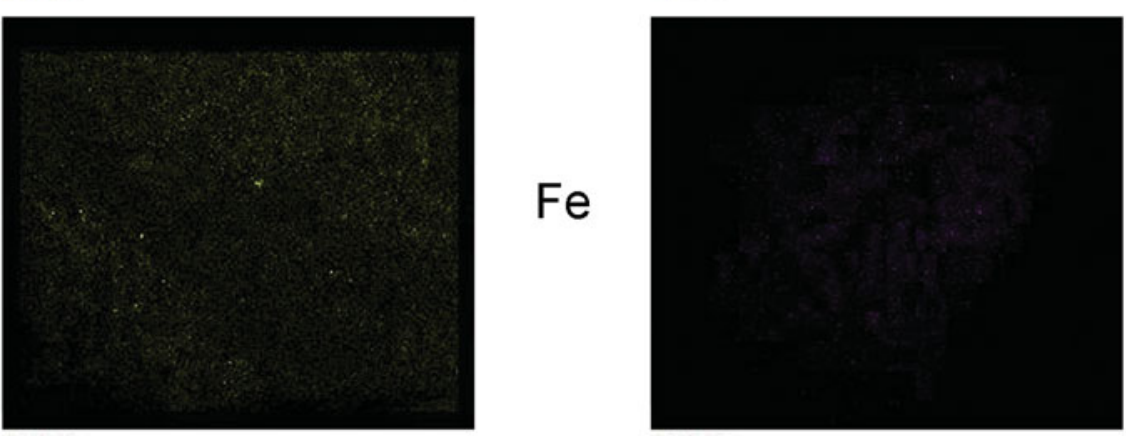

Fe Ka1

Fe Ka1

Figure 7. SEM and EDX spectroscopy; charred rodent femur (left) and heavily oxide-stained rodent metapodia (right). The femur shows minimal $M n$ and Fe deposits that do not follow the pattern of oxide staining. The metapodial shows, however, a high content of Mn indicating that the colour follows patterns of oxide-stained deposition. Additional information is available in online supplementary material.

(C) Antiquity Publications Ltd, 2016 


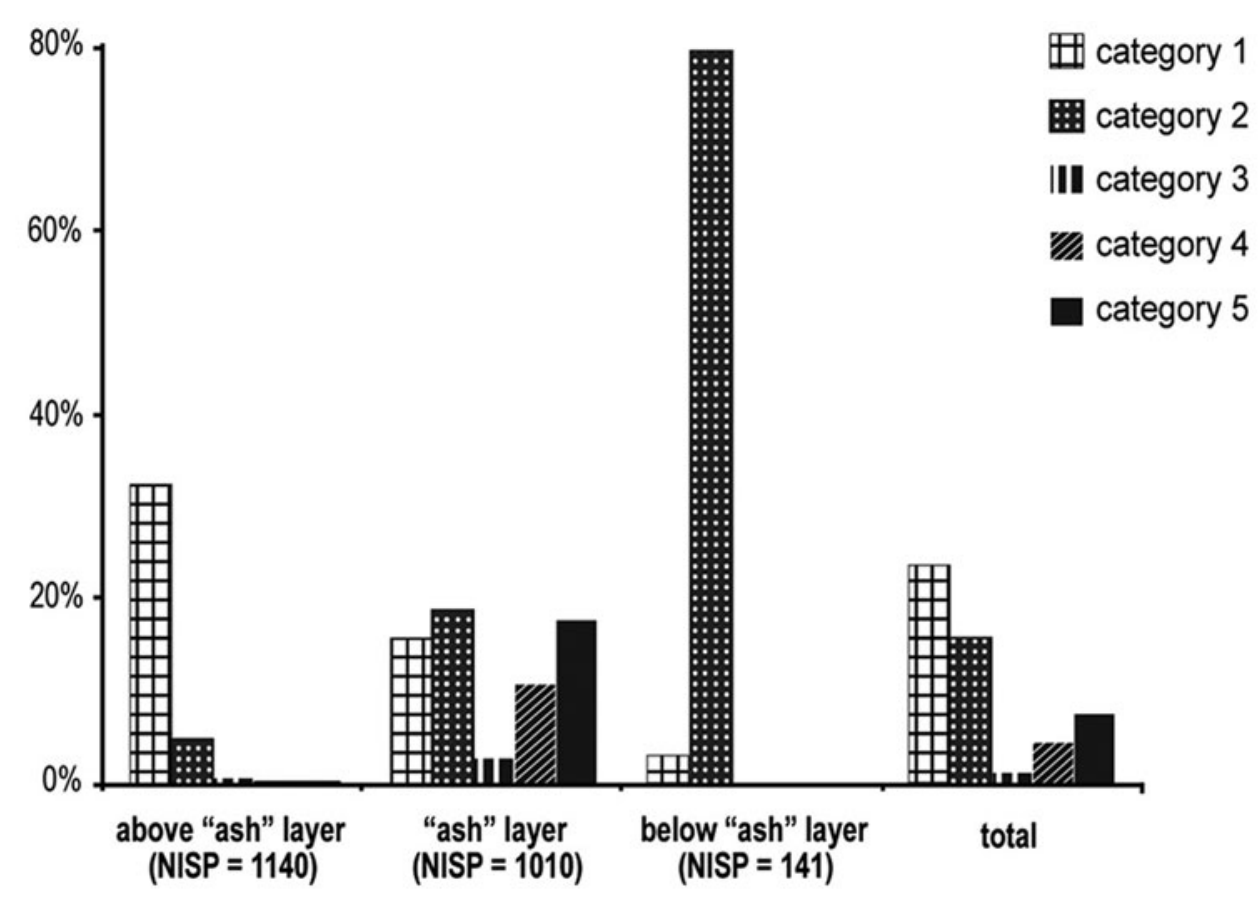

Figure 8. Comparative study of approximately 2300 small-mammal bone fragments excavated in 2011 from above, within and below the 'ash' layer. The categories of burning span minimum reddish discolouration (Category 1) to complete calcination (Category 5). $97 \%$ of all charred and calcined bone identified came from the 'ash' layer. A statistically significant difference was found in the proportion of heavily burnt bone (categories 3-5) from within the 'ash' layer versus overlying deposits $(\chi 2=169.2 ; p<0.001)$.

et al. 2014, forthcoming), 25\% showed evidence of thermal alteration as discolouration of bone surface (Figure 8). The deeply lying sediment provided around $95 \%$ of all micro-mammalian specimens inspected from CNERQ that corresponded to categories 3-5 in Figure 8; furthermore, in that sediment, bones from different anatomical regions were affected alike, which is compatible with in situ exposure to high temperature. Although excavation of the deep sediment recovered fragments of large mammals ( $>80$, around 20 of which showed signs of thermal alteration) and tortoise, the taphonomic study was devised with the particular methodological purpose of comparing and contrasting remains of micromammals from different parts of the site and to consider their source (following Andrews 1990), which is most likely to have been predation by owls, lynxes or foxes, doubtless during periods of absence by humans, who perhaps burnt rubbish on their return and may have roasted foodstuffs.

e) Detailed examination of the deeply lying sediment containing burnt chert and bone (Figure 9) reported that "distinct layers were observed of materials resembling ash, sometimes resting on reddened belts" (Angelucci et al. 2013: 198), although incontrovertible highresolution microscopical evidence of combustion, such as in situ reddening, presence of (C) Antiquity Publications Ltd, 2016 


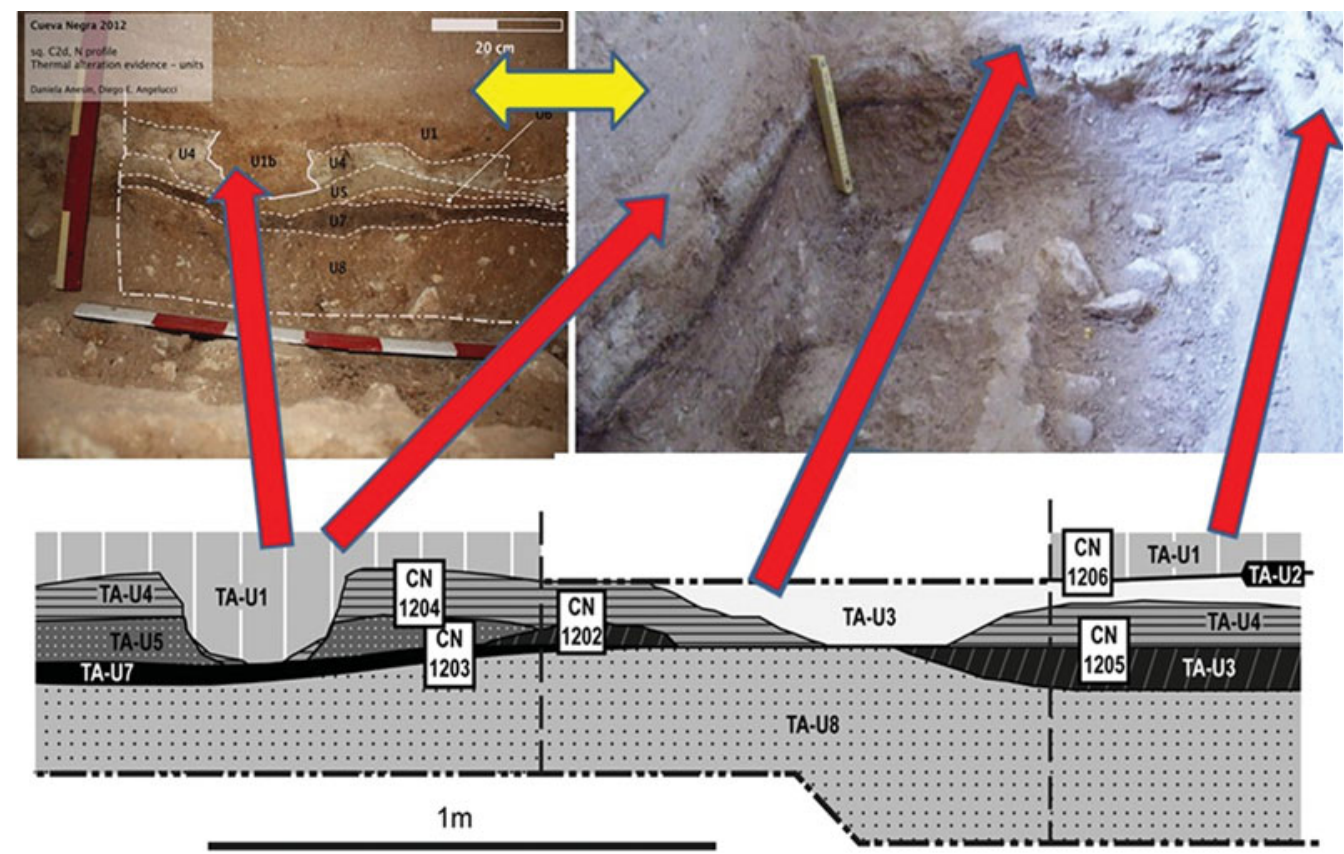

Figure 9. Photographs and stratigraphy of deeply lying sedimentary layers with burnt remains in metre-square C2d during excavation in 2012. Adapted from supplementary information in Angelucci et al. (2013). See online supplementary material for description of unit characteristics and features.

wood ash or charcoal fragments, was not detected in the thin sections on which sediment micromorphology was undertaken.

f) Chemical and mineral investigation compared the deep reddened sediment with sediment above and below by thermogravimetric analysis with mass spectrometry, granulometry (of the $<2 \mathrm{~mm}$ fraction) using laser diffraction, and XRF and XRD studies. Hydroxyapatite present in the reddened sediment (2.5\%), and in the sediment immediately below it (1\%), is compatible with the degradation of bone; it was also found in an excavated burnt chert fragment $(0.2 \%)$.

Samples: sediment samples were analysed from reddish layer TA-U6 and the underlying layer TA-U7, and compared to one from overlying sediment. A burnt chert fragment was also analysed.

Principal findings: samples from TA-U6 and TA-U7 contained $\mathrm{CaCO}_{3}$ inclusions as microscopic clumps and fine powder. Organic content: $1.45-1.8 \%$. Organic $\mathrm{CO}_{2}: 20-$ 21.5\%. TA-U6 and TA-U7 consist mainly of $\mathrm{CaCO}_{3}$ (c. 90.5\%), and hydroxyapatite $\mathrm{Ca}_{10}\left(\mathrm{PO}_{4}\right)_{6}(\mathrm{OH})_{2}$ (TA-U6 2.5\%P; TA-U7 1\%P) (c. 2\%), which is compatible with the degradation products of bone. Elements present at $>1 \%$ : $\mathrm{O}(48 \%), \mathrm{Ca}(20-24 \%)$, Si (10-12\%), C (6\%), Al (4-4.5\%), Fe (2-2.5\%), P (1-2.5\%), K (1.6-1.8\%), Mg (1\%). Elements present at <1\%: $\mathrm{Na}, \mathrm{S}, \mathrm{Cl}, \mathrm{Ti}, \mathrm{V}, \mathrm{Cr}, \mathrm{Mn}, \mathrm{Ni}, \mathrm{Cu}, \mathrm{Zn}, \mathrm{Br}, \mathrm{Rb}, \mathrm{Y}$, Zr, Ba. 
Mineral species identified (percentages):

Calcite Quartz Muscovite ?Sanidine Clinochlore Hydroxyapatite Illite Haematite

\begin{tabular}{|c|c|c|c|c|c|c|c|c|}
\hline $\begin{array}{l}\text { Overlying } \\
\text { sediment }\end{array}$ & $71.0 \%$ & $22.3 \%$ & $2.1 \%$ & $0 \%$ & $2.2 \%$ & $1.2 \%$ & $0.7 \%$ & $0.3 \%$ \\
\hline TA-U6 sample & $57.8 \%$ & $27.6 \%$ & $7.6 \%$ & $1.9 \%$ & $1.9 \%$ & $2.2 \%$ & $0.5 \%$ & $0.5 \%$ \\
\hline TA-U7 sample & $50.6 \%$ & $29.4 \%$ & $7.8 \%$ & $6.8 \% *$ & $2.8 \%$ & $1.9 \%$ & $0.4 \%$ & $0.2 \%$ \\
\hline
\end{tabular}

${ }^{*}$ Further research will attempt to improve the characterisation of this mineral, which appears to be sanidine.
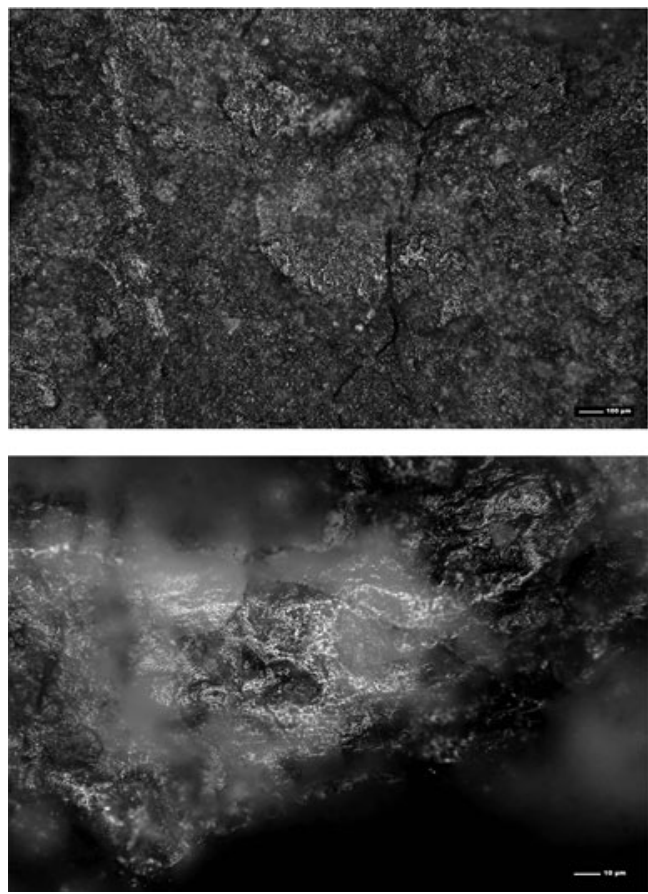

Figure 10. Microscopy of chert fragments shows thermal alteration (top) and thermal patination (bottom). g) Microscopy reveals that grey hues predominate on surfaces of chert excavated in unit VI sediment affected by combustion. Vertical and oblique fractures are frequent (giving rise to tiny spalls), as are conspicuous oval or circular shallow depressions caused by thermal alteration of chert surfaces. Cracks and reticulate crazing are widespread, particularly on surfaces showing rubefaction. White opaque or translucid patination is frequent, as is shiny thermal lustre that can seem slightly 'greasy'. The macroscopic and microscopic observations at CNERQ are in line with similar observations at other archaeological sites showing evidence of combustion, and also with experimental findings (cf. Luedtke 1992; Clemente Conte 1997). Photomicrographs show thermal alteration and surface patination of thermally altered CNERQ chert specimens (Figure 10).

\section{Early fire and mid-Quaternary human evolution}

The findings imply combustion $c .0 .8 \mathrm{Ma}$ at CNERQ. What are the archaeological implications? Claims of early Palaeolithic fire must be treated cautiously. Alleged evidence of fire from ancient cave sites can seem convincing (James 1989) but warning bells are sounded by much-discussed difficulties of interpretation at well-known sites. At CNERQ, previous comments (Walker et al. 2006) were limited to prudent cursory mention of small bones with 'signs of burning' excavated in higher sediments, and, in relation to a $1 \mathrm{~m}^{2}$ test-pit dug in 2004, to "loose sediment flecked with carbon (unit V = layer and spits 5a-5g). It passes into unit VI, which is half-a-metre thick, and is distinguished by zones of very dark, loose soil, suggestive of burning (unit VI = layer and spits 6a through 6i)" (Walker et al. 2006:

(C) Antiquity Publications Ltd, 2016 
8), although post-depositional diagenetic decalcification could be responsible. The small test-pit reached bed-rock in 2004, but its vertical profiles and sediment with neither burnt chert nor burnt bone failed to show the sedimentary sequence of the adjacent $2 \mathrm{~m}^{2}$ that have now provided burnt fragments of bone and chert. In these $2 \mathrm{~m}^{2}$ the bed-rock slopes slightly downwards towards the test-pit square, determining drainage of nearby sediments. In the test-pit, deeply lying sediment (of units V and VI $=$ layers 5 and $6=$ complex 3-2 of Angelucci et al. 2013) contains organic residues, doubtless derived from the adjacent $2 \mathrm{~m}^{2}$, albeit lacking both pollen and microscopic traces of charcoal. Our 2006 caution owed to a possibility that ash could have been blown inside from bush-fires sweeping past the cave mouth; it may account for burnt traces in 1.2 Ma sediments at Sima del Elefante (Sierra de Atapuerca, northern Spain): "L'abondance de micro-charbons associés à des composés organo-minéraux exogènes atteste de la récurrence d'incendies naturels dont le déclenchement semble être lié à des évènements exceptionnels d'origine cosmique" [The abundance of micro-carbons associated with exogenous organic-mineral compounds is testimony to recurring natural fires probably caused by exceptional atmospheric phenomena] (Carbonell et al. 2010: 12).

Roebroeks and Villa (2011: supplementary information p. 1) wrote:

heated fints in a cave site are unlikely to be the result of natural wild fires and may be considered a reliable indicator of anthropogenic fire if (i) there is no evidence of reworking of sediments, slope wash, or debris flow entering the cave; (ii) the excavator noted a localized concentration of heated fint and bones; and (iii) only a small proportion of heated flint occurs at the site. This combination of evidence suggests a good probability of localized fire.

This combination occurs at CNERQ.

'Anthropogenic fire' refers to the generation of fire. Although hot sparks given off by a wooden hand-drill, or pyrite being struck with chert, could have ignited carefully prepared tinder at CNERQ, this begs the question of how cognitive appreciation arose of a possibility of making fire by bringing together two different kinds of technical behaviour-namely, selecting and preparing different kinds of wood (e.g. mullein and clematis) or suitable stones for striking sparks, and selecting and preparing suitable tinder for sparks to set alight (NB whereas pyrite occurs in some rock strata near Caravaca, none has been excavated in the cave). Prerequisites could have included advantages gained opportunistically from tending fire, itself a probable consequence of a reduction of instinctive pyrophobia (fear of fire, reinforced by skin-burns). Evidence of fire inside an early Palaeolithic cave carries implications for understanding cognitive evolution. The argument is set out briefly below.

First, it is unlikely that sparks from a bush-fire outside, perhaps caused by lightning, could set alight a chance accumulation of brushwood inside, such as to bring about a roaring blaze within, causing high temperatures. Moreover, the river and its swamp lay in front of the cave, where gallery woodland flourished in a damp environment, not a dry one. The cave roof also probably then extended outwards farther than it does today (as it may well have undergone some erosive reduction); if so, then the signs of fire we have uncovered would have been still farther back inside than the current $5-7 \mathrm{~m}$. Perhaps smouldering brands or embers left behind by bush-fires nearby were carried inside so that fire could be tended where 
rain or wind could not extinguish it. No fire-pit or hearth stones have been found, therefore there is no evidence of ability to control the heat of a tended fire. Nevertheless, from the standpoint of cognitive evolution, it is plausible that the people at the cave had less fear of fire outside than did animals seen fleeing before it. That could have led them to meddle with fire in order to drive animals towards natural death-traps, such as swamps, where they could be dismembered.

A tended fire in a cave serves several purposes: providing warmth, roasting food and deterring approach by animals. Compelling physiological arguments exist for cooking playing a part in human evolution from c. 1.5 Ma. Wrangham (2009: 88-90) wrote that archaeological "hints from the Lower Paleolithic tell us only that [...] the control of fire was a possibility, not a certainty" and "[T] he inability of the archaeological evidence to tell us when humans first controlled fire directs us to biology [...] At some time our ancestors' anatomy changed to accommodate a cooked diet". With regard to the evolution of human anatomy, following attainment, c. 1.6 Ma, of more-or-less modern stature, it is a plausible conjecture that subsequently widespread noteworthy increases in cerebral volume in Homo erectus and $H$. heidelbergensis, and, eventually, $H$. neanderthalensis and $H$. sapiens, were enabled by the enhanced digestion and absorption of nutrients that cooking afforded to pregnant women, lactating mothers, infants and children (cf. Fonseca-Azevedo \& Herculano-Houzel 2012). Outcomes of cognitive evolution are reflected in the extensive material record of Palaeolithic technology (and pyrotechnology) from Middle and Late Pleistocene times, not to mention the late Early Pleistocene at CNERQ. The bifacial flaking of its handaxe is matched in Mediterranean Spain by that of a cleaver excavated in an even earlier deposit at Barranc de la Boella (Vallverdú et al. 2014), and an assemblage of small artefacts at Vallparadís (Martínez et al. 2010) shares several features with those from CNERQ.

As CNERQ has provided both an 'Acheulean' bifacially flaked handaxe and abundant flakes made by repetitive centripetal flaking of small, sometimes discoidal, cores for producing retouched small tools, it exemplifies the ability of those who frequented it to select and carry out different self-determining or self-constraining Palaeolithic chains of sequential behavioural activities (Walker 2009; Walker et al. 2013, 2016; Zack et al. 2013). Survival of early humans in middle latitudes laid heavy evolutionary demands on their cognitive versatility and manual dexterity, which are attested by the diversity of the CNERQ artefacts, so it is unsurprising that they may have tended fire. More than one palaeospecies of late Early Pleistocene Homo may have engaged, opportunistically, in behaviour with fire. The skilfulness manifested by 'Acheulean' artefacts at sites with traces of fire implies evolution of cognitive versatility sufficient for such behaviour.

Fire characterises the 'Acheulean' Gesher Benot Ya'akov site at the onset of the Brunhes chron, c. $078 \mathrm{Ma}$ (Goren-Inbar et al. 2004; Alperson-Afil \& Goren-Inbar 2010; Richter et al. 2011; Alperson-Afil 2012). Barely $140 \mathrm{~km}$ south-west of CNERQ, magnetostratigraphy identified the "Matuyama-Brunhes boundary only a few metres below the fossil/toolbearing levels" (Scott \& Gibert 2009: 82) at the open Solana del Zamborino site, where excavation uncovered five stones surrounding a possible hearth area containing carbonised wood ("madera carbonizada", Botella López et al. 1976: 28) and burnt bone, although burnt remains were also excavated over a wider area; the site provided two bifacially flaked handaxes and small retouched artefacts.

(C) Antiquity Publications Ltd, 2016 
Fire occurred in the South African Wonderwerk Cave with 'Acheulean' artefacts during the Jaramillo subchron, c. 1.07-0.99 Ma (Berna et al. 2012). Although other late Early Pleistocene sites with evidence of combustion are known in Africa from $c .1 .5 \mathrm{Ma}$ onwards (Gowlett et al. 1981; Rowlett 2000), most are open sites where bush-fires might have been responsible (Berna et al. 2012, who do not exempt Gesher Benot Ya'akov in that regard, contra Richter et al. 2011; Alperson-Afil 2012). At Swartkrans Cave, evidence of combustion (Skinner et al. 2004) from Member 3, containing 'Acheulean' artefacts, is subject to uncertainty about the integrity and age of the member, with dates from 1.4 to $0.6 \mathrm{Ma}$ (Herries et al. 2009; Berna et al. 2012), although plausible ones are $0.96 \pm 0.09 \mathrm{Ma}$ by ${ }^{26} \mathrm{Al} /{ }^{10} \mathrm{Be}$ (Gibbon et al. 2014) and $0.83 \pm 21 \mathrm{Ma}$ by U-Pb (Balter et al. 2008).

'Acheulean' artefacts are unknown at Zhoukoudian Locality 1 , where $\operatorname{six}{ }^{26} \mathrm{Al} /{ }^{10} \mathrm{Be}$ estimates of c. $0.77 \pm 0.08 \mathrm{Ma}$ (Shen et al. 2009) come from levels 7-10, which also have 17 estimates $c .0 .55-0.35 \mathrm{Ma}$ from ${ }^{230} \mathrm{Th} /{ }^{234} \mathrm{U}$, TL, ESR and fission-track methods (Goldberg et al. 2001). Layer 8 is correlated with the laterally separate 'quartz horizon 2' where 'ash' was reported (Pei 1932; Teilhard de Chardin \& Pei 1932; Black et al. 1933). Chemical signs of combustion exist in later levels 4-6 (Zhong et al. 2013), notwithstanding micromorphological demonstration of post-depositional diagenetic alteration. This also affected deeper layers 7-10, causing mistaken identification of 'ash' features; burnt bone from slightly above them is incompatible with in situ combustion (Goldberg et al. 2001).

In England, excavation at Beeches Pit, with 'Acheulean' artefacts c. 0.42-0.37 Ma, uncovered features hypothesised as putative hearths for "controlled fire-use" (Gowlett et al. 2005: 32), and "occurrence of bones burned to grey or white [...] implies more intense combustion than is usual for a natural fire, which often results in only partial and superficial burning (David 1990)" (Preece et al. 2006: 492). At c. $0.3 \mathrm{Ma}$, hearth features at Qesem Cave in Israel (Karkanas et al. 2007; Shahack-Gross et al. 2014) imply repeated use of fire in a restricted space enabling heat-control.

From the standpoint of mid-Quaternary human evolution, it is intriguing that in Africa, Israel and now at CNERQ, convincing signs of combustion occur at several sites where Palaeolithic assemblages include bifacially flaked stone artefacts. A tempting surmise is that the conjunction reflects the cognitive versatility and technical ability of early humans, which played a part in facilitating their dispersal into middle latitudes.

\section{Acknowledgements}

Alfonso Burgos Risco is thanked for Figures 4, 5, 6, 8 and 9, based on the authors' colour slides. Régis Braucher is thanked for sampling CNERQ sediments and attempting ${ }^{26} \mathrm{Al} /{ }^{10} \mathrm{Be}$ dating at the CEREGE-LN2C National Laboratory for Cosmogenic Nuclides at Aix-Marseilles University. We are grateful for helpful attention from palaeontologists Jan van der Made of the Department of Palaeobiology at Madrid's National Museum of Natural Sciences, Gloria Cuenca Bescós of the Department of Earth Sciences at the University of Saragossa, and Antonio Ruiz Bustos of the Andalusian Institute of Earth Sciences at the University of Granada, and from palaeopalynologist José S. Carrion of the Department of Plant Biology at the University of Murcia. Small mammal analyses were funded by Spanish project CGL2010-19825, a Canadian SSHRC grant awarded to M. Chazan, and SSHRC and University of Toronto financial assistance to S.E. Rhodes. 


\section{Supplementary material}

To view supplementary material for this article, please visit http://dx.doi.org/ 10.15184/aqy.2016.91.

\section{References}

ALPERSON-AfIL, N. 2012. Archaeology of fire: methodological aspects of reconstructing fire history of prehistoric archaeological sites. Earth-Science Reviews 113: 111-19. http://dx.doi.org/10.1016/j.earscirev.2012.03.012

Alperson-Afil, N. \& N. Goren-Inbar (ed.). 2010. The Acheulean site of Gesher Benot Ya'aqov, volume II: ancient flames and controlled use of fire. London: Springer. http://dx.doi.org/10.1007/978-90-481-3765-7

ANDREWS, P.J. 1990. Owls, caves and fossils: predation, preservation and accumulation of small mammal bones in caves, with an analysis of the Pleistocene cave faunas from Westbury-sub-Mendip, Somerset, United Kingdom. London: Natural History Museum.

Angelucci, D.E., D. Anesin, M. LÓpez Martínez, M. Haber Uriarte, T. Rodríguez Estrella \& M.J. WALKER. 2013. Rethinking stratigraphy and site formation of the Pleistocene deposit at Cueva Negra del Estrecho del Quípar (Caravaca de la Cruz, Spain). Quaternary Science Reviews 80: 195-99. http://dx.doi.org/10.1016/j.quascirev.2013.09.009

Balter, V., J. Blichert-Toft, J. Braga, P. Telouk, F. ThaCKeray \& F. AlbarÈDE. 2008. U-Pb dating of fossil enamel from the Swartkrans Pleistocene hominid site, South Africa. Earth and Planetary Science Letters 267: 236-46. http://dx.doi.org/10.1016/j.epsl.2007.11.039

Berna, F., P. GoldberG, L.K. HorWitz, J. BrinK, S. Holt, M. BAMFord \& M. CHAZAN. 2012. Microstratigraphic evidence of in situ fire in the Acheulean strata of Wonderwerk Cave, Northern Cape province, South Africa. Proceedings of the National Academy of Sciences of the USA 109: 7593-94. http://dx.doi.org/10.1073/pnas.1117620109

Black, D., P. Teilhard de Chardin, C.C. Young \& W.C. PEI. 1933. Fossil man in China. Memoirs of the Geological Survey of China series A 11: 1-166.

Botella lópez, M.C., I. Marqués Merelo, A. DE Benito Ontañón, A.C. Ruiz Rodríguez \& M.T. Delgado RuIz. 1976. La excavación y sus resultados arqueológicos, in M.C. Botella López, J.A. Vera Torres \& J. de Porta Vernet (ed.) El yacimiento achelense de la "Solana del Zamborino", Fonelas (Granada) (Primera campaña de excavaciones) (Cuadernos de Prehistoria de la Universidad de Granada 1): 25-49. Granada: Universidad de Granada.
Carbonell, E., J. Vallverdú Poch \& M.-A. Courty. 2010. Le cadre paléoenvironnemental et culturel des premières occupations humaines d'Europe: le karst de la Sierra d'Atapuerca (Burgos, Espagne), in Résumés, "GéoKARST: regards croisés des géosciences sur le karst”, Séance spécialisée FFG-AFEQ-AFK-CNF-INQUA, 9 décembre 2010: 12. Paris: Société Géologique de France.

Carrión, J.S., E.I. Yll, M.J. Walker, A.J. LegaZ, C. Chain \& A. López. 2003. Glacial refugia of temperate, Mediterranean and Ibero-North African flora in south-eastern Spain: new evidence from cave pollen at two Neanderthal man sites. Global Ecology and Biogeography 12: 119-29. http://dx.doi. org/10.1046/j.1466-822X.2003.00013.x

Clemente Conte, I. 1997. Thermal alterations of flint implements and the conservation of microwear polish: preliminary experimental observations, in A. Ramos Millán \& M.A. Bustillo (ed.) Siliceous rocks and culture: 525-35. Granada: Universidad de Granada.

DAVID, B. 1990. How was this bone burnt?, in S. Solomon, I. Davidson \& D. Watson (ed.) Problem solving in taphonomy: archaeological and palaeontological studies from Europe, Africa and Oceania (Tempus: Archaeology and Material Culture Studies in Anthropology 2): 65-79. Saint Lucia: Anthropology Museum, University of Queensland.

Debénath, A. \& H.I. DibBle. 1994. Handbook of Paleolithic typology, volume 1: Lower and Middle Paleolithic of Europe. Philadelphia: University Museum, University of Pennsylvania.

FernándeZ-Jalvo, Y. \& M.D. Avery. 2015. Pleistocene micromammals and their predators at Wonderwerk Cave, South Africa. African Archaeological Review 32: 751-91. http://dx.doi.org/10.1007/s10437-015-9206-7

Fonseca-AzEvedo, K. \& S. Herculano-Houzel. 2012. Metabolic constraint imposes tradeoff between body size and number of brain neurons in human evolution. Proceedings of the National Academy of Sciences of the USA 109: 18571-76. http://dx.doi.org/10.1073/pnas.1206390109

Gibbon, R.J., T.R. Pickering, M.B. SutTon, J.L. Heaton, K. Kuman, R.J. Clarke, C.K. Brain \& D.E. Granger. 2014. Cosmogenic nuclide burial dating of hominin-bearing Pleistocene cave deposits at Swartkrans, South Africa. Quaternary Geochronology 24: 10-15. http://dx.doi.org/10.1016/j.quageo.2014.07.004

(C) Antiquity Publications Ltd, 2016 


\section{Findings, context and significance of combustion at the late Early Pleistocene}

Goldberg, P., S. Weiner, O. Bar-Yosef, Q. Xu \& J. LIU. 2001. Site formation processes at Zhoukoudian, China. Journal of Human Evolution 41: 483-530. http://dx.doi.org/10.1006/jhev.2001.0498

Goren-Inbar, N., A. Alperson, M.E. Kislev, O. Simchoni, Y. Melamed, A. Ben-Nun \& E. WERKER. 2004. Evidence of hominin control of fire at Gesher Benot Ya'aqov, Israel. Science 304: 725-27. http://dx.doi.org/10.1126/science.1095443

GOWLETT, J.A.J., J.W.K. HARRIS, D. WALTON \& B.A. WoOD. 1981. Early archaeological sites, hominid remains and traces of fire from Chesowanja, Kenya. Nature 294: 125-29. http://dx.doi.org/10.1038/294125a0

Gowlett, J.A.J., J. Hallos, S. Hounsell, V. Brant \& N.C. Debenham. 2005. Beeches Pit: archaeology, assemblage dynamics and early fire history of a Middle Pleistocene site in East Anglia, UK. Eurasian Prehistory 3: 3-38.

Herries, A.I.R., D. Curnoe \& J.W. AdAms. 2009. A multi-disciplinary seriation of early Homo and Paranthropus bearing palaeocaves in southern Africa. Quaternary International 202: 14-28. http://dx.doi.org/10.1016/j.quaint.2008.05.017

JAMES, S.R. 1989. Hominid use of fire in the Lower and Middle Pleistocene. Current Anthropology 30: 1-26. http://dx.doi.org/10.1086/203705

Jiménez-Arenas, J.M., M. SAntonja, M. Botella \& P. PALMQVIST. 2011. The oldest handaxes in Europe: fact or artefact? Journal of Archaeological Science 38: 3340-49. http://dx.doi.org/10.1016/j.jas.2011.07.020

Karkanas, P., R. Shahack-Gross, A. Ayalon, M. BAR-MatThews, R. BARKaI, A. FrUmKIN, A. Gopher \& M.C. STINER. 2007. Evidence for habitual use of fire at the end of the Lower Paleolithic: site formation processes at Qesem Cave, Israel. Journal of Human Evolution 53: 197-212. http://dx.doi.org/10.1016/j.jhevol.2007.04.002

LUEDTKE, B.E. 1992. An archaeologist's guide to chert and flint (Archaeological Research Tools 7). Los Angeles (CA): UCLA Institute of Archaeology.

Martínez, K., J. García, E. Carbonell, J. Agustí, J.-J. Bahain, H.-A. Blain, F. Burjachs, I. CÁceres, M. Duval, C. Falguères, M. Gómez \& R. HugueT. 2010. A new Lower Pleistocene archaeological site in Europe (Vallparadís, Barcelona, Spain). Proceedings of the National Academy of Sciences of the USA 107: 5262-67. http://dx.doi.org/10.1073/pnas.0913856107
Martínez Andreu, M., R. Montes BernÁrdez \& M. SAN NiCOLÁS DEL TORO. 1989. Avance al estudio del yacimiento musteriense de la Cueva Negra de La Encarnación (Caravaca, Murcia), in Crónica XIX Congreso Nacional de Arqueología, Castellón de la Plana 1987, Ponencias y Comunicaciones volumen I: 973-83. Zaragoza: Universidad de Zaragoza.

PEI, W.C. 1932. Notice on the discovery of quartz and other stone artifacts in the Lower Pleistocene hominid-bearing sediments of the Chou Kou Tien cave deposit. Bulletin of the Geological Society of China 11: 110-41.

Preece, R.C., J.A.J. Gowlett, S.A. Parfitt, D.R. BRIDGLAND \& S.G. LEWIS. 2006. Humans in the Hoxnian: habitat, context and fire use at Beeches Pit, West Stow, Suffolk, UK. Journal of Quaternary Science 21: 485-96. http://dx.doi.org/10.1002/jqs. 1043

RHODES, S.E. 2014. Evidence for opportunistic fire use during the late Early Palaeolithic at Cueva Negra del Estrecho del Río Quípar, Murcia, Spain: a micro mammal taphonomic approach. Unpublished MSc dissertation, University of Toronto.

Rhodes, S.E., M.J. WalKer, M. LÓPEZ-MartíneZ, M. Haber-Uriarte \& A. López-Jiménez. 2014. Evidence for cultivated fire during the late Early Paleolithic in southeastern Spain: preliminary results from a micromammal taphonomic approach. Paper presented at the $12^{\text {th }}$ International Conference of the International Council on ArchaeoZoology, San Rafael, Mendoza, Argentina, 22-27 September 2014.

Rhodes, S.E., M.J. WalKer, A. LÓPEZ-JimÉnEZ, M. López-Martínez, M. Haber-Uriarte $\&$ M. Chazan. Forthcoming. Fire in the Early Palaeolithic: evidence of small mammal incidental burning at Cueva Negra del Estrecho del Río Quípar. Submitted to Journal of Archaeological Science.

RiCHTER, D. 2007. Feuer und Stein-Altersbestimmung von steinzeitlichem Feuerstein mit Thermolumineszenz, in G.A. Wagner (ed.) Einführung in die Archäometrie: 33-49. Berlin: Springer. http://dx.doi.org/10.1111/j.1475-4754.2010. 00581.x

Richter, D., N. Alperson-Afil \& N. Goren-Inbar. 2011. Employing TL methods for the verification of macroscopically determined heat alteration of flint artefacts from Palaeolithic contexts. Archaeometry 53: 842-57.

Roebroeks, W. \& P. Villa. 2011. On the earliest evidence for the habitual use of fire in Europe. Proceedings of the National Academy of Sciences of the USA 108: 5209-14. http://dx.doi.org/10.1073/pnas.1018116108 
RowletT, R.W. 2000. Fire control by Homo erectus in East Africa and Asia. Acta Anthropologica Sinica 19: 198-208.

SCHŌN, W. 2012. Veränderungen an Steinartefakten durch Wind, Hitze und Frost, in H. Floss (ed.) Steinartefakten vom Altpaläolithikum bis in die Neuzeit: 101-104. Tübingen: Kerns.

ScotT, G.R. \& L. GiberT. 2009. The oldest hand-axes in Europe. Nature 461: 82-85.

http://dx.doi.org/10.1038/nature08214

Shahack-Gross, R., F. Berna, P. Karkanas, C. Lemorini, A. Gopher \& R. Barkai. 2014. Evidence for the repeated use of a central hearth at Middle Pleistocene (300 ky ago) Qesem Cave, Israel. Journal of Archaeological Science 44: 12-21. http://dx.doi.org/10.1016/j.jas.2013.11.015

Shen, G., X. GaO, B. GaO \& D.E. Granger. 2009. Age of Zhoukoudian Homo erectus determined with ${ }^{26} \mathrm{Al} /{ }^{10} \mathrm{Be}$ burial dating. Nature 458: 198-200. http://dx.doi.org/10.1038/nature07741

SKINNER, A.R., J.L. LloYd, C.K. Brain \& F. THACKERAY. 2004. Electron spin resonance and the controlled use of fire. Abstract A26a Poster Session, Paleoanthropology Society Annual Meeting, Montreal, Canada, 30 March 2004.

Teilhard de Chardin, P. \& W.C. Pei. 1932. The lithic industry of the Sinanthropus deposits at Choukoutien. Bulletin of the Geological Society of China 11: 315-65.

http://dx.doi.org/10.1111/j.1755-6724.1932. mp11004001.x

UBERLAKER, D.H. 1999 [2004]. Human skeletal remains. Excavation, analysis, interpretation (Manuals on Archeology 2). Washington, D.C.: Taraxacum.

Vallverdú, J., P. Saladié, A. Rosas, R. Huguet, I. CÁCERES, M. MOSQUERA,

A. Garcia-Tabernero, A. Estalrrich,

I. Lozano-Fernández, A. Pineda-Alcalá,

A. Carrancho, J.J. Villalaín, D. Bourlès, R. Braucher, A. Lebatard, J. Vilalta, M. ESTEBAN-NADAL, M.L. BENNÀSAR, M. BASTIR, L. López-Polín, A. Ollé, J.M. Vergé, S. Ros-Montoya, B. Martínez-NaVArro, A. García, J. Martinell, M. Expósito, F. Burjachs, J. Agustí \& E. Carbonell. 2014. Age and date for early arrival of the Acheulean in Europe (Barranc de la Boella, la Canonja, Spain). PLoS ONE 9(7): e103634.

http://dx.doi.org/10.1371/journal.pone.0103634

WALKER, M.J. 2009. Long-term memory and Middle Pleistocene 'Mysterians', in S.A. de Beaune,

F.L. Coolidge \& T. Wynn (ed.) Cognitive archaeology and human evolution: 75-84. Cambridge \& New York: Cambridge University Press.

(C) Antiquity Publications Ltd, 2016
Walker, M.J., J. Gibert, E. EASTHAM,

T. Rodríguez-Estrella, J.S. Carrión, E.I. Yll, A.J. Legaz, A. López, M. López \& G. Romero. 2004. Neanderthals and their landscapes: Middle Palaeolithic land use in the Segura drainage basin and adjacent areas of southeastern Spain, in N.J. Conard (ed.) Settlement dynamics of the Middle Palaeolithic and Middle Stone Age, volume 2

(Tübingen Publications in Prehistory 2): 461-511. Tübingen: Kerns.

Walker, M.J., T. Rodríguez Estrella, J.S. Carrión GARCÍA, M.A. MANCHEÑO JiMÉNEZ, J.-L. SCHWENNINGER, M. LÓPEZ MARTÍNEZ, A. López Jiménez, M. SAN NiCOlÁs DEL Toro, M.D. Hills \& T. WalkLing. 2006. Cueva Negra del Estrecho del Río Quípar (Murcia, southeast Spain): an Acheulean and Levalloiso-Mousteroid assemblage of Palaeolithic artifacts excavated in a Middle Pleistocene faunal context with hominin skeletal remains. Eurasian Prehistory 4: 3-43.

WALKer, M.J., M.V. LÓPEZ-MarTínez, J.S. Carrión-García, T. Rodríguez-Estrella, M. SAN-NICOLÁS-DEL-TORO, J.-L. SCHWENNINGER, A. LÓPEZ-JimÉnEZ, J. ORTEGA-RODRIGÁÑEZ, M. Haber-Uriarte, J.-L. Polo-Camacho, J. García-Torres, M. Campillo-BoJ, A. AvilÉs-FernándeZ \& W. ZaCK. 2013. Cueva Negra del Estrecho del Río Quípar (Murcia, Spain): a late Early Pleistocene site with an 'Acheulo-Levalloiso-Mousteroid' Palaeolithic assemblage. Quaternary International 294: 135-59. http://dx.doi.org/10.1016/j.quaint.2012.04.038

Walker, M.J., D. Anesin, D. Angelucci,

A. Avilés-Fernández, F. BERna,

A.T. Buttrago-López, J.S. Carrión, A. Eastham, S. FernándeZ-Jiménez, J. García-Torres, M. Haber-Uriarte, A. López-Jiménez, M.V. López-Martínez, I. Martín-Lerma, J. Ortega-RodrigÁNez, J.-L. Polo-Camacho, S.E. RHODES, D. RICHTER,

T. RodrígueZ-Estrella, G. ROMERO-SÁnCHEZ, M. SAN-NICOLÁS-DEL-TORO, J.-L. SCHWENNINGER, A.R. SKINNER, J. VAN DER MADE \& W. ZACK. 2016. Palaeolithic activity ca. $0.8 \mathrm{Ma}$ at Cueva Negra del Estrecho del Río Quípar (Caravaca de la Cruz, Murcia, southeastern Spain): some reflections on fire, technological diversity, environmental exploitation, and palaeoanthropological avenues. Human Evolution 31: 1-67.

WRANGHAM, R. 2009. Catching fire: how cooking made us human. New York: Basic; London: Profile. 
Zack, W., A. Andronikov, T. RodrígueZ-Estrella, M. López-MARTíneZ, M. HABER-URIARTE, V. Holliday, D. Lauretta \& M.J. WalKer. 2013. Stone procurement and transport at the late Early Pleistocene site of Cueva Negra del Estrecho del Río Quípar (Murcia, SE Spain). Quartär, Internationales Jahrbuch zur Eiszeitalter- und

Steinzeitforschung/International Yearbook for Ice Age and Stone Age Research 60: 7-28.
Zhong, M., C. Shi, X. GaO, X. Wu, F. Chen, S. ZhANG, X. ZhANG \& J.W. Olsen. 2013. On the possible use of fire by Homo erectus at Zhoukoudian, China. Chinese Science Bulletin 59: 335-43.

http://dx.doi.org/10.1007/s11434-013-0061-0

Received: 26 March 2015; Accepted: 6 August 2015; Revised: 2 September 2015 